\title{
Retail Format Selection in On-the-Go Shopping Situations
}

\author{
Sabine Benoit* \\ Professor in Marketing \\ Department for Marketing and Retail Mgt., Surrey Business School, \\ Guildford, GU2 7XH, UK and
}

College of Business and Economics at Australian National University (ANU), Canberra ACT 2601, Australia

Tel.: +44 (0)1483 68 6338; Email: s.benoit@ surrey.ac.uk

\begin{abstract}
Heiner Evanschitzky
Professor in Marketing

Aston Centre for Retail Insights (ACRI), Aston Business School, Birmingham, B4 7ET, UK

Tel.: +44 (0) 121204 3113; Email: h.evanschitzky@aston.ac.uk
\end{abstract}

\section{Christoph Teller}

Professor in Retailing and Marketing, Department of Marketing and Retail Mgt., Surrey Business School Guildford, GU2 7XH, UK

Tel.: +44 (0)1483 68 3981; Email: c.teller@ surrey.ac.uk

* Corresponding author 


\title{
Retail Format Selection in On-the-Go Shopping Situations
}

\begin{abstract}
Consumers patronize different store formats to purchase products. Prior literature describes store and format choices for big, multi-item shopping baskets, but limited insights determine consumers' unique shopping routines when they seek to buy just one or a few items while on the go. Such shopping situations might affect consumers' format selections for both search and experience goods. This study uses multi-attribute utility theory to develop a framework, tested with a scenario-based experiment. For search goods, a format's economic utility (price level, speed) is more important; its functional utility (quality, variety) and psychological utility (atmosphere, service) become less important considerations. Furthermore, the tolerable range of formats is larger for search goods. The level of on-the-go purchase and consumption frequency moderates these effects. Therefore, this research helps to clarify what drives consumers' format selections in on-the-go shopping situations, with useful managerial insights for how retailers can compete in the growing on-the-go market.
\end{abstract}

Keywords: retail format, shopping situation, experiments, food, choice, on-the-go consumption 


\section{Introduction}

Food to go and convenience are considered to be ubiquitous megatrends in food and beverage consumption, as evidenced by the variety of channels - such as convenience stores, food service restaurants, and coffee shops-found in all major Western metropolitan areas (Ipsos, 2018). Accordingly, the market share of small-format retailers, such as convenience stores, continues to grow due to their appeal to consumers who shop "little and often" and need "food/beverages on the go," often at the expense of larger formats such as hypermarkets (IGD, 2018; Nielsen, 2015; PMA, 2017). In the U.S. alone, nearly 155,000 convenience stores accounted for $\$ 550$ billion in annual sales (NACS, 2017), "one of the fastest growing grocery retail sectors globally" (Skoda, 2017, "Here to stay," para. 2). In particular for on-the-go shopping for food and beverages, consumers are offered a wide choice among a variety of formats (Kamran-Disfani, Mantrala, Izquierdo-Ysta, \& Martínez-Ruiz, 2017) such as coffee shops, fast food restaurants, and even discounters. Consumers select these different formats depending on the product category that they seek (Nielsen, 2015) and thus their shopping situation (Dellaert, Arentze, \& Timmermans, 2008; Van Kenhove, de Wulf, \& van Waterschoot, 1999).

Existing literature on retail (format) patronage choices mainly considers the following situation-specific variables: different products (Dellaert et al., 2008), task descriptions (Van Kenhove et al., 1999), and basket sizes (Bell, Ho, \& Tang, 1998; Hunneman, Verhoef, \& Sloot 2017; Reutterer \& Teller, 2009; Thelen \& Woodside, 1997). It also provides significant insights related to large, multi-item shopping baskets. However, few studies address different shopping situations such as on-the-go scenarios (see Table 1). Findings about drivers of retail patronage choices in large-basket situations do not necessarily apply to on-the-go situations, because consumers' practices and preferences differ across these settings (Hunneman et al., 2017). When 
they are on the go, for example, consumers are unlikely to produce a shopping list (Bell et al., 1998) or proceed through as many decision-making stages before selecting a format (Balasubramanian, Raghunathan, \& Mahajan, 2005; Valentini, Montaguti, \& Neslin, 2011). Onthe-go purchases and needs represent lower financial risk (Sweeney, Soutar, \& Johnson, 1999) but greater urgency to consumers (Hunneman et al., 2017; Reutterer \& Teller, 2009). On-the-go situations also trigger decision and shopping processes that reduce transaction costs (Bell et al., 1998; Reutterer \& Teller, 2009). Consumers on regular shopping trips aim to minimize transaction costs, whereas consumers pursuing urgent purchases display more flexibility when satisfying their needs (Emmelhainz, Stock, \& Emmelhainz, 1991). Such situation-specific behavior becomes relevant when investigating the format selection and the tolerable range of formats that a consumer is willing to turn to. Format selections differ for more frequent shoppers too, such that those who are more familiar with shopping feel minimal risk but are also less responsive to marketing (Choudhury, Dumm, \& Karahanna-Evaristo, 1999; Valentini et al., 2011). Thus, in on-the-go situations in general, as well as depending on the product category, consumers might select formats that differ from their conventionally preferred options.

To address this research question, the current study investigates how two different on-thego shopping situations might influence retail format selections. A search good, relative to an experience good, might alter the importance of various format attributes that provide functional, economic, or psychological utilities, and thus determine format selection. With this prediction, the current study seeks to make three contributions: First, to advance retail patronage literature, we develop a framework of consumers' format selections in on-the-go shopping contexts. Second, we test this framework empirically, using an online experiment with two different products (search goods and experience goods) and an expansive set of seven alternative retail 
formats. Third, we offer managerial insights into the drivers of format selection in different onthe-go shopping situations to provide guidance for retail managers in this increasingly competitive landscape.

The conceptual and theoretical foundation of this study relies on two key streams of literature: retail patronage literature that identifies relevant criteria for retail format selections and multi-attribute utility theory that provides predictions about format selections according to risk-minimization, utility-maximization rationales. Combining these insights, we develop a novel conceptual framework, SAU-FS (situation-attributes—utility—format selection), which we test empirically in an online experiment with shopper data from 514 consumers who shop in seven formats. We discuss our results and their main theoretical and practical implications, and then conclude with some limitations of the study and an outlook for further research.

\section{Retail format selection when on the go: Conceptual foundation and hypotheses}

\subsection{Retail image and format attributes}

A retailer's store and format image are represented by more or less salient attributes, and previous research proposes various frameworks to describe them (e.g., Bloemer \& de Ruyter, 1998; Sirohi, McLaughlin, \& Wittink, 1998). Early frameworks excluded retail services as determinants of format selection, which proved inadequate (Arnold, Handelman, \& Tigert, 1996). Instead, key attributes relate to individual products and the entire assortment (productrelated attributes), as well as the process or service offering (service-related attributes) (Balasubramanian et al., 2005, Mazursky \& Jacoby, 1986; Reutterer \& Teller, 2009). Accordingly, we propose a framework that captures six important product- and service-related attributes: quality, variety, price level, speed of retail services, service level, and atmosphere (Blut, Teller, \& Floh, 2018; Fox, Montgomery, \& Lodish, 2004; Valentini et al., 2011). 
The quality of an assortment influences retail patronage; it is distinct from the retailer's service quality (Baker, Parasuraman, Grewal, \& Voss, 2002; Blut et al., 2018). Most prior frameworks of retailer selection or patronage include the quality of the assortment (Baker et al., 2002; Bloemer \& de Ruyter, 1998; Sirohi et al., 1998). This refers to perceptions of the merchandise, as well as the variety of brands and categories (Sirohi et al., 1998). Retail formats also offer different levels of assortment variety (Bhatnagara \& Ratchford, 2004), such that convenience stores carry narrower assortments, whereas hypermarkets carry wider ones (Messinger \& Narasimhan, 1997; Mitchell, 1998). Traditionally, retailers have widened their assortments to enable consumers to find their preferences (Bhatnagara \& Ratchford, 2004) or to optimize their time by combining purchases of different categories in one-stop shopping situations (Popkowski Leszczyc, Sinha, \& Sahgal, 2004). More recently, research also recognized how wide assortments can trigger choice overload, with potentially negative effects (Gourville \& Soman, 2005). Finally, price is a key format selection criterion (Arnold et al., 1996; Blut et al., 2018), and stores and formats differ in their applied pricing strategies (Bhatnagara \& Ratchford, 2004). The price level can even trigger visits to a retail store that is less convenient (Woodside \& Trappey, 1992), and the importance of price rises with basket size (Van Kenhove et al., 1999).

With regard to service-related attributes, the expected speed of the service and wait time strongly affect store patronage intentions (Grewal, Baker, Levy, \& Voss, 2003). Because many consumers feel time pressures and engage in the "pursuit of efficiency-producing behaviors" (Pan \& Zinkhan 2006, p. 232), speed and the time costs of shopping are relevant criteria for retail format selections (Dellaert et al., 2008; Messinger \& Narasimhan, 1997). Bloemer and de Ruyter (1998) also suggest that the general service level, as manifested in personalized services and 
extended opening hours, can enhance shoppers' motivation and ability to judge the retailer and its stores positively overall. Retail services enhance the shopping experience and thereby influence consumer patronage decisions (Blut et al., 2018). The atmosphere consists of visual, aural, olfactory, and tactile variables (McGoldrick, 2002), including music, crowd density, and temperature. Shoppers use these atmospheric cues to evaluate retailers and make inferences about their overall performance (Baker et al., 2002). Therefore, the format's atmosphere influences retail images (Bloemer \& de Ruyter, 1998) and store patronage (Blut et al., 2018; Grewal et al., 2003).

Including six attributes in the framework is in line with previous research that indicates that consumers' format selections depend on as few as three to five attributes (Woodside \& Trappey, 1992). These attributes also represent the most relevant components of a store's image and thus influence patronage behavior; however, product-related attributes are core, and servicerelated ones are more peripheral (Mazursky \& Jacoby, 1986). Previous research offers some foundation but does not specify which attributes are most relevant in on-the-go shopping situations. This is surprising given the growing importance of on-the-go shopping and consumption for retailers.

\subsection{Search and experience goods}

In contrast to existing research on format selection (see Table 1), we investigate the importance of the aforementioned six attributes depending on the shopping situation rather than on a more abstract and general level. This is important since the shopping situation strongly influences consumer behavior (Belk, 1974; Blut et al., 2018; Miller \& Ginter, 1979). Situation specificity refers to all the factors that have demonstrable, systematic effects related to a time, place, and task of a selection, rather than the format or consumer variables (Belk, 1974). For 
research into consumers' format selections to be meaningful to managers, the findings must reflect the precise situational context from the consumers' perspective (Dellaert et al., 2008), because "the concept of situation becomes managerially important if ... relative strengths and weaknesses differ by situation" (Miller \& Ginter, 1979, p. 111).

\section{-- Table 1 about here --}

Previous literature has mainly focused on larger baskets and weekly shopping trips (see Table 1 and Bell et al., 1998; Dellaert et al., 2008; Popkowski Leszczyc \& Timmermanns, 2001; Valentini et al., 2011), whereas research on small baskets is rare (Reutterer \& Teller, 2009; Thelen \& Woodside, 1997). There are few studies investigating the role of product types in the context of channel and format selection. Product types, such as search and experience goods, have shown to impact consumer behavior. This typology is based on the extent to which consumers feel that they need to directly experience and interact with the goods to assess their quality. Search goods can be evaluated without interacting with the product through second-hand information, whereas experience goods require interaction with the product by potentially using someone's senses (Huang, Lurie, \& Mitra, 2009; Weathers, Sharma, \& Wood, 2007). Thus, purchasing experience goods presents a higher risk than purchasing search goods (Maity \& Dass, 2014). Retailers and manufacturers aim to lower purchasing risk by branding their products, thus making the purchase predictable. A high brand equity represents the aforementioned secondhand information, which lowers purchasing risk and transforms an experience good into a search good (Srinivasan and Till, 2002). Consumers have shown themselves to be less concerned about a retailer's reputation when buying nationally branded products, since the quality of the product will be less dependent on the retailer (Ekelund, Mixon, Ressler, \& Rand, 1995).

\section{Insert Figure 1 here}




\section{Figure 1: Selection, risk, and quality perception for search \& experience goods}

\subsection{On-the-go shopping situations and frequency}

On-the-go purchases and consumption have become more frequent, and thus understanding consumers' format selections for few items and the impact of the shopping situation on purchase behavior has become vital for retailers (Ipsos, 2018). However, most research on format selections focuses on situational attributes that relate to trips for larger, multi-item baskets such as major or weekly shopping trips (see Table 1 and Bell et al., 1998; Dellaert et al., 2008; Popkowski Leszczyc \& Timmermanns, 2001; Valentini et al., 2011). Few studies investigate smaller baskets (Reutterer \& Teller, 2009; Thelen \& Woodside, 1997) or selection criteria that relate to the basket size for different tasks.

In addition to literature not having captured small-basket shopping situations very well, it has not captured very frequent shopping trips very well either. Most research on retail patronage uses the frequency of visits over time to one particular retailer, i.e., loyalty (e.g., Blut, et al., 2018). However, for some categories — including groceries - consumers' store loyalty is rather limited (Popkowski Leszczyc et al., 2000). Our study focuses on format selection across formats and retailers; thus, we are interested in the frequency of the behavior in general and not the frequency of visiting a particular retailer. This is important because shopping frequency has shown to matter in other contexts. For example, Van Kenhove et al. (1999) show that for regular (but large-quantity) purchases, price is more important than in various other situations, whereas store design and assortment play relatively minor roles. Theelen and Woodside (1997) show that for daily, more frequent shopping trips, the proximity of the store to the home is more important than for large (less frequent) stock-up trips. This suggests the need to clarify the impact of purchase frequency on format selections. 


\subsection{Multi-attribute utility theory and defining the tolerable format range}

Multi-attribute utility theory (Wallenius et al., 2008) proposes that a decision maker who chooses between alternatives evaluates them according to the expected utility of the outcomes. The set of alternatives can be small and finite or large and infinite, such that the former results in a choice problem and the latter in an optimization problem. Every decision also creates the risk of a poor choice of an alternative that is high in costs and low in benefits, with low overall utility (Conchar, Zinkhan, Peters, \& Olavarrieta, 2004). The utility evaluation is based on various criteria (Wallenius et al., 2008) and thus comprises different forms, including functional (or performance), economical (or financial), and psychological utilities (Sweeney et al., 1999). Functional utility in on-the-go consumption settings pertains to the core functions of the retail store or product, such as selling a certain type of product. Economic utility relates to (not) wasting money and/or time. Psychological utility for on-the-go consumption implies a feeling of (dis)satisfaction with the store or the product (Jacoby \& Kaplan, 1972; Sweeney et al., 1999).

In turn, the anticipated utility has two components: the importance of each utility level and its probability (Conchar et al., 2004). A low utility level might be very unlikely but very severe (e.g., food contaminated with bacteria, leading to serious illness) or likely but not very severe (e.g., a product being out of stock). Therefore, according to multi-attribute utility theory, a person chooses the alternative that is either the most preferred optimal option or else good enough to terminate the decision process (Wallenius et al., 2008). To reduce their risk of suffering a low utility level, consumers thus estimate its probability and its severity, and seek some tolerable level (Conchar et al., 2004; Mitchell, 1998). As described above, the different product types relate to different levels of risk, because in contrast to experience goods, search goods can be evaluated without interacting with the product (Huang et al., 2009; Weathers et al., 
2007).

These theoretical arguments can be applied to retail format selections regarding buying either search or experience goods, which involve decisions in which consumers consider multiple variables related to the retailer and the product (e.g., atmosphere and price), then make a choice based on the expected utility (Noble, Griffith, \& Weinberger, 2017). In a shopping situation that creates an immediate demand for a certain product (Hunneman et al., 2017), consumers realistically face a finite set of options, limited by the physical availability of formats and the proximity of stores at the time that the urgent need occurs, such as convenience stores, supermarkets, or forecourt stores. Therefore, format selection in on-the-go consumption represents a choice problem (Dellaert et al., 2008). The focus on immediate/urgent on-the-go consumption is relevant because the decision-making patterns likely differ in these cases. Theory suggests that consumers might choose retail formats that are not optimal but rather that are tolerable. However, previous research mainly looked at the format selection of one format in isolation rather than in comparison with other formats (see Table 1). In turn, it is important to understand the underlying mechanisms (Conchar et al., 2004) and investigate what bandwidth is considered "tolerable" depending on the shopping situation (i.e., product type) and how it relates to retail format attributes.

As discussed previously, retail format attributes (quality, variety, price, atmosphere, service level, and speed) should affect consumers' anticipated format utility: The quality and variety of the assortment relate to functional utility — according to whether or not the product performs according to expectations (Jacoby \& Kaplan, 1972; Kushwaha \& Shankar, 2013), or is (not) available and thus can(not) achieve its purpose. The price and speed of service define the required consumer resources in terms of time and money, so they can produce economic utility 
that influences format selection (Jacoby \& Kaplan, 1972). Finally, service and atmosphere are linked to psychological utility, in that they have the potential to tarnish the experience (Jacoby \& Kaplan, 1972; Kushwaha \& Shankar, 2013). Figure 2 depicts this framework and the hypothesis.

\section{-- Figure 2 about here -}

\section{Figure 2: SAU-FS framework: situation-attributes-utility-format selection}

Format utility or different format attributes may also differ in importance, depending on the product category (Dholakia, 2001; Ekelund et al., 1995). The extent to which consumers feel that they need to directly experience and interact with a good to evaluate its quality (i.e., search versus experience goods; Huang et al., 2009; Weathers et al., 2007) impacts the importance of different format attributes. This is because when it comes to branded food products—classified as search goods in this research-consumers will be less concerned with the reputation of a retailer (Ekelund et al., 1995) since they feel that less risk is attached to this purchase (Maity \& Dass, 2014). This is in line with Alfnes, Rickertsen, and Ueland (2009), who found that consumers perceive unprocessed and semi-processed food (often unbranded and experience goods) to be associated with greater utility risk than processed food (often brands and search goods), because the control mechanisms imposed in mass food production and the strategic goals of branding in reducing pre-purchase risk (Heiman \& Muller, 1996) lead to very low variability in quality.

Consumers can reduce the chances that they suffer low utility to some tolerable level by applying different risk-mitigation strategies (Mitchell, 1998; Wallenius et al., 2008) such as searching for information, postponing and contemplating, relying on brands or retailer images, and avoiding alternatives with low utility (Derbaix, 1983; Sheth \& Venkatesan, 1968). Few onthe-go consumption situations trigger strategies that demand high transaction costs such as a high 
effort to search for information (Bell et al., 1998). Instead, the most likely strategies for consumers on the go are relying on brands and/or relying on retailer images to avoid low utility alternatives. To capture these two strategies, the proposed model compares purchase situations for a search good, in which case the product brand serves as a signal and thus risk reducer for consumers, with purchase situations for an experience good, in which consumers will rely more on the retailer's image (Ekelund et al., 1995) and as such avoid frequenting certain format alternatives, which are detailed subsequently.

Functional utility. Branding in fast-moving consumer goods (FMCG) sectors informs consumers about expected product attributes (Erdem \& Swait, 1998) so that consumers can reduce the chances of low utility levels by relying on brands (Sheth \& Venkatesan, 1968). However, perceived risk is higher for experience goods than for search goods because the probability of an unwanted outcome is lower for search goods (Maity \& Dass, 2014). Because a brand represents a search attribute, buying brands should be associated with higher utility levels (Sheth \& Venkatesan, 1968). In a retail format selection context, when consumers seek to buy a search good (e.g., bottled water, soft drinks), the danger of a low utility level is minimal. In contrast, if they want to buy an experience good (e.g., freshly prepared coffee) with more service components, the potential of low functional utility increases, so this format attribute becomes more important.

Economic utility. Price acts as an indicator of quality for consumers (Zeithaml, 1988). Search attributes inform consumers about expected product quality (Erdem \& Swait, 1998), therefore when they can rely on a search attribute as an indication of expected product quality, they do so; if search attributes are less available, price becomes more important as a quality indicator (Zeithaml, 1988). Thus, price might be more important for experience goods than for 
search goods. Furthermore, on-the-go shopping situations usually do not trigger activities that demand high transaction costs (Bell et al., 1998); for example, long expected wait times decrease consumers' likelihood of selecting a certain store (Grewal et al., 2003; Teller, Kotzab, \& Grant, 2011). When consumers buy search goods, the price and waiting time that they must invest to make their purchases are clear sacrifices, thus they likely aim to minimize both by carefully selecting the retail format. For an experience good with more service components (e.g., a flavored hot coffee, personalized and freshly prepared on site), the price and having to wait instead become part of the experience, signaling its quality. Thus, consumers of experience goods might not select a retail format with the goal of minimizing these factors to the same extent. That is, a low price and speedy service (economic gains) may be less important to the retail format selection of consumers buying experience goods for their on-the-go consumption. Psychological utility. The atmosphere of a retail format is another key cue that consumers use to evaluate retailers and make inferences about their overall performance (Baker et al., 2002). Similar to the reasoning for price as a quality indicator (Zeithaml, 1988), atmospheric cues should have less impact for search goods because the search attributes, not the retail outlet, have signaling power (Erdem \& Swait, 1998). For soft drinks or bottled water, store-based retailers function mainly to make products available by selling and promoting them in stores. To create competitive advantages, retailers might enhance their service level and provide distinctive services that are difficult to imitate, which require complex, difficult managerial efforts. For example, managers must train staff to provide a high level of personal service, customize products, or prepare them on-site. For experience goods that already involve a higher service component, the retailer can thus influence the value created (Watson, Worm, Palmatier, \& Ganesan, 2015). The potential of a low utility level, due to choosing a suboptimal retail format, 
increases when consumers are seeking products with substantial service components. Similarly, research on convenience and specialty goods shows that for low-effort convenience goods, the retailer's service quality is relatively unimportant (Pan \& Zinkhan, 2006). Therefore, when buying search goods, the atmosphere and service level may be less important criteria for retail format selections.

$H_{1 a}:$ To select formats in an on-the-go consumption situation, functional format utility is less important for consumers who buy search goods as opposed to experience goods. $H_{1 b}$ : To select formats in an on-the-go consumption situation, economic format utility is more important for consumers who buy search goods as opposed to experience goods. $H_{1 c}$ : To select formats in an on-the-go consumption situation, psychological format utility is less important for consumers who buy search goods as opposed to experience goods. Formats differ in the utility that they deliver to consumers (Choudhury et al., 1999). Expected utility reflects evaluations of the anticipated costs and benefits of each format (Sweeney et al., 1999). Among the many formats available to consumers (Hunneman et al., 2017), the most relevant ones for on-the-go purchases include small supermarkets, discount stores, convenience stores, and specialty stores (Bhatnagara \& Ratchford, 2004; Reutterer \& Teller, 2009; Popkowski Leszczyc et al., 2004; Watson et al., 2015).

According to multi-attribute utility theory, decision makers choose either the optimum or a good-enough option (Wallenius et al., 2008). The optimal format is the one with the highest expected utility, reflecting the combined importance of the three utility dimensions, spanning the six store attributes and the expected performance of different formats. When one attribute (e.g., price) is very important to a consumer, it influences the format selection more than other criteria (e.g., variety), so the format's expected performance regarding this criterion (e.g., price value of 
a format) influences the format choice to a greater extent.

However, because on-the-go shopping situations rarely trigger in-depth considerations (Bell et al., 1998), a shopper might not engage in the effort to find the retail format with the highest expected utility but instead accept a format that is good enough (Wallenius et al., 2008) - that is, within a "tolerable range." These tolerable ranges should differ, depending on whether consumers buy search goods that they can evaluate in advance or experience goods that evoke more risk because they can only be evaluated after consumption (Maity \& Dass, 2014; Nelson, 1970). In turn, for search goods, the actual product should provide the main indicator of quality, and the format attributes become less important. Retailers mainly need to make products available to consumers, so the formats and their attributes become largely interchangeable. For search goods, the tolerable range of the retail format selection should thus be wider. In contrast, for experience goods, the retailer exerts a higher influence on the product — and product risk is higher-so consumers might fear low utility levels, such that they develop a narrower tolerable range of store formats. Formally,

$\mathrm{H}_{2}$ : Consumers shopping for search goods while on the go have a wider tolerable range of retail formats than those shopping for experience goods.

Finally, retail format selection also depends on consumer attitudes, preferences, and past patronage behavior and intentions (Blut et al., 2018; Fox et al., 2004; Valentini et al., 2011). For example, someone with less frequent exposure to on-the-go purchase (and consumption) occasions - who thus displays a lower degree of behavioral loyalty toward on-the-go formats and is less familiar with the retail environment - is more challenged by making their format selections (Blut et al., 2018; Valentini et al., 2011). By contrast, shoppers who more regularly engage with purchases on the go and thus have a better knowledge of retailers or formats 
experience less uncertainty in their selection decisions (Choudhury et al., 1999). Therefore, frequent on-the-go shoppers can evaluate a retail format's potential utility at a lower cost and with less risk. In turn, they should be less affected by the shopping situation (search/experience good) compared to infrequent shoppers, leading to a wider tolerance range that makes them more willing to depart from an optimal retail format.

$H_{3}$ : The impact of the shopping situation (search versus experience good) on the tolerable range of retail formats for on-the-go consumption is stronger for frequent onthe-go shoppers.

\section{Methodology}

\subsection{Experimental design, manipulation, and sample}

To test our framework, we used a vignette-based experiment embedded in a selfadministered online questionnaire. To operationalize on-the-go shopping situations with different risk levels (Maity \& Dass, 2014), the scenarios refer to a search good that can be evaluated before the purchase (bottled water or a soft drink) and an experience good that can only be evaluated after its purchase (freshly prepared hot drink; Nelson, 1970). Generally, both products are available in the suggested retail formats of the chosen retail market. In the empirical setting for this study, both types of products tend to feature manufacturer brands (e.g., Evian, CocaCola, Starbucks, Segafredo, Lavazza, etc.). However, the water / soft drink has more search attributes related to the manufacturer brand, whereas the hot drink features fewer search attributes and more experience attributes because it is prepared in the store by staff members. We developed the questionnaire and experimental manipulation on the basis of prior literature and in collaboration with four wholesale managers who have expertise in on-the-go shopping markets and who work with different retail clients operating various store formats. To 
ensure that the survey respondents understood the context of on-the-go food shopping, the questionnaire started with questions about their probability of encountering such shopping situations (e.g., buying bottled water, snacks, soft drinks, or coffee to go). Then in the experimental manipulation, a scenario asked respondents to imagine buying either a branded, prepackaged drink (search good) or a freshly prepared hot drink (experience good). A manipulation check (three items, adapted from Chaudhuri, 1998, $\alpha=.772$ ) confirms that risk perceptions for the search good were lower than those for the experience good $\left(\mathrm{M}_{\text {experience }}=2.87\right.$, $\left.\mathrm{M}_{\text {search }}=2.37, p<.01\right)$. The measure of on-the-go purchase and consumption frequency used a five-point scale, borrowed from Benoit, Schaefers, and Heider $(2016, \alpha=.848$; see the Appendix).

A professional market research firm recruited the sample, and $514^{1}$ German-speaking consumers completed the questionnaire. The market research firm was instructed to use quotas to achieve representation of the overall population in terms of age and gender. The average age in the sample is 42.2 years, and $54.6 \%$ are women.

\subsection{Dependent variables}

This study includes two dependent variables: (1) the importance of functional, economic, and psychological format utilities when selecting a format; and (2) the tolerable range of formats. In line with prior literature (Blut et al., 2018; Fox et al., 2004; Valentini et al., 2011), we used the six previously described retail format attributes and linked them to three utility categories: functional (quality and variety), economic (price and speed), and psychological (service and atmosphere; Figure 2). To start, we measured the importance of the utility components by asking respondents to allocate $100 \%$ across all six attributes. The test of $\mathrm{H}_{1 \mathrm{a}-\mathrm{c}}$ used two items to measure

\footnotetext{
${ }^{1}$ The sample size was $\mathrm{n}=514$ for all analyses except for assessing the impact of risk on zone of tolerance, where we had 85 missing values because the combined utilities reported did not add up to 100 .
} 
functional utility $(r=-.192, p<.01)$, two items to measure economic utility $(r=-.245, p<.01)$, and two items to measure psychological utility $(r=.370, p<.01) .{ }^{2}$ We evaluated the impact of the search versus experience good manipulation on the importance of these utility dimensions. Then, to test $\mathrm{H}_{2}$ and $\mathrm{H}_{3}$, we sought to capture the tolerable range of retail formats from which consumers would be willing to purchase. Thus, we applied our proposed SAU-FS framework in several steps, as detailed in Figure 3. We first developed a list of relevant formats for on-the-go shopping, based on available market share data from different industry sources. The wholesale experts reviewed this list and confirmed seven formats: supermarkets, discounters, bakeries, forecourt stores, corner shops, fast food stores, and coffee shops. Next, to calculate the (weighted) expected utility of each format, we asked the respondents to evaluate this expected attribute utility with regard to the retail attributes (quality, variety, price, speed, service, and atmosphere) on seven-point scales anchored by "very negative" (1) and "very positive" (7). We subsequently weighted the expected utility by the importance of each attribute, as specified by respondents (100 points distributed across all dimensions and for all formats). This step enabled us to calculate the weighted expected utility of each of the seven formats.

\section{-- Figure 3 about here-}

\section{Figure 3: Weighted expected utility of formats}

To derive the tolerable range of retail formats, for each respondent we calculated the difference between the format with the highest weighted expected utility (optimal format) and the format with the lowest weighted expected utility that they still visited for the manipulated product within the previous four weeks, indicating that it was "good enough" (see Figure 4). The

\footnotetext{
${ }^{2}$ While functional risk is highest when quality and variety are most important, and economic risk is highest when price and convenience are most important, we note a negative correlation between the two items to measure functional utility and the two items to measure economic utility. This suggests that customers make trade-offs between quality and variety (functional risk) as well as between price and convenience (economic risk).
} 
four-week, concrete time limit helps enhance the validity of the results, because when studying situation specificity, more specific time frames yield more reliable results (Goldsmith, Freiden, \& Eastman, 1995). For example, for respondent A, the coffee shop had the highest expected utility, but A also indicated buying a coffee in the bakery and fast food store in the previous four weeks. The format with the lowest expected utility marks one end of the tolerable range, and the optimal format is the other end. Formats that the respondents did not choose fall outside this tolerable range.

\section{-- Figure 4 about here -}

\section{Figure 4: Tolerable range of format}

\section{Results}

The tests of the hypotheses rely on both multivariate analyses of variance (MANOVA) for $\mathrm{H}_{1 \mathrm{a}-\mathrm{c}}$ and analyses of variance (ANOVA) for $\mathrm{H}_{2}$ and $\mathrm{H}_{3}$. The search good versus experience good manipulation is the independent variable (IV); the format utility dimensions and format selection are dependent variables (DV). The results in Table 1 indicate that for search goods, functional and psychological format utilities are less important considerations for retail format selection (cf. experience goods), in line with $\mathrm{H}_{1 \mathrm{a}}$ and $\mathrm{H}_{1 \mathrm{c}}$. Conversely, economic utility is more important for format selection for search goods compared with experience goods, confirming $\mathrm{H}_{1 \mathrm{~b}}$ as well. Turning to $\mathrm{H}_{2}$, we find that the tolerable range of formats for a search good purchase is significantly wider than that for an experience good purchase $\left(\mathrm{M}_{\text {search }}=128.05 ; \mathrm{M}_{\text {experience }}=\right.$ 99.13; $p<.01) .{ }^{3}$ This interesting finding suggests that consumers are more particular about their selection of format when they perceive the purchase as riskier, because it has fewer search

\footnotetext{
${ }^{3}$ To validate the results, we replicated the experiment with another product category relevant to on-the-go consumption: snacks. A pre-packaged snack such as a chocolate bar, ice cream, or salty snack served as the search good $(\mathrm{n}=$ 127); a freshly prepared snack such as a filled roll, salad, or hot snack was the experience good $(\mathrm{n}=126)$. The results similarly support the hypotheses. These results are available on request.
} 
attributes. In line with this interpretation, respondents in the experience good condition considered 2.168 formats on average, whereas those in the search good condition indicated having visited significantly more formats, at $2.579(\mathrm{~F}=3.943 ; \mathrm{p}<.05)$. Finally, we assessed whether the impact of the consumption situation (search good versus experience good) on the tolerable range of formats was moderated by consumers' on-the-go purchase and consumption frequency. The marginally significant moderation of experience is in line with $\mathrm{H}_{3}(p<.1, F=$ 1.583). We also note two significant main effects of the search/experience good manipulation $(p$ $<.01, F=8.947)$ and purchase frequency $(p<.01, F=2.408)$. Less frequent shoppers have considered 1.94 formats in the past, compared with the 3.44 formats $(p<.01, t=16.891)$ considered by more frequent shoppers.

-- Table 2 about here --

\section{Implications}

\subsection{Implications for theory}

Impact of the shopping situation on retail format selection. This study addresses a persistent literature gap regarding consumers' format selections for more immediate, on-the-go shopping trips. In so doing, it contributes to the literature on retail format selection in general (Blut et al., 2018) and the impact of the shopping situation on format selection in particular (Van Kenhove et al., 1999). We find clear evidence that format selection depends on the shopping situation. By testing these aspects in an on-the-go shopping situation, we complement findings obtained with larger baskets (Bell et al., 1998; Messinger \& Narasimhan, 1997), which require consumers to go through various decision stages before selecting a retail format (Balasubramanian et al., 2005; Valentini et al., 2011).

Conceptualization of situational impacts on format selection. Complementing work by 
Blut et al. (2018), we contribute to retail patronage literature by developing a conceptual framework in which the shopping situation affects the importance of retail format attributes, linked to three utility dimensions: quality and variety (functional), price and speed of service (economic), and the atmosphere and service (psychological). We argue that format selection is an outcome of a decision process. It reflects the degree to which shoppers perceive the capability of a format and its utility to fulfill their expectations. We name the proposed framework SAUFS, to highlight the situation-attributes-utility-format selection elements.

Consumption situation and format utility dimensions in format selection. Departing from Van Kenhove et al. (1999), this research expands the current understanding of the impact of the shopping situation associated with the product category and on-the-go consumption. We test whether purchasing a search or experience good affects which utility dimensions are most important for selecting a format. The findings reveal that for search goods, functional and psychological format utilities are less of a concern for shoppers when choosing a format, whereas economic utility is more important. When buying search goods, consumers do not fear that the channel will influence their quality, so the atmosphere and service become negligible. Previous research similarly indicates that for low-effort convenience goods, people overlook retail service quality (Pan \& Zinkhan, 2006). We also complement Bell et al.'s (1998) studies of large baskets and reveal that the danger of low economic utility (losing money or time) is more important for search goods, for which consumers seek to avoid high transaction costs such as those imposed by waiting in line.

Shopping situations and tolerable ranges. Consumers patronize ranges of formats, and the number of formats that they consider differs across shopping situations. For search goods, consumers consider a wider range of formats. Take this example: When consumers look to buy a 
Coke, they would be willing to visit 2.65 formats on average, but if they were trying to purchase a fresh potentially personalized coffee, they would consider only 2.14 formats. For search goods, a considerable number of consumers still visit their third-most preferred format, but they would not expand their consideration set this far if they wanted to buy an experience good. We can thus conclude that consumers who buy experience goods are willing to accept higher transaction costs to access their preferred format.

Role of the on-the-go purchase and consumption frequency. We investigated how experience might affect format selection. Adding to Choudhury et al.'s (1999) findings, we show that increased on-the-go shopping frequency widens the number of formats considered across different shopping situations. For search goods, a more frequent shopper considers a wider range of retail formats than less frequent on-the-go shoppers do.

\subsection{Managerial implications}

Understanding on-the-go shopping. Store-based retailers must understand not just their customers but also their specific shopping situations. With such an understanding, they can make more informed investment decisions with regard to how to improve store attributes and marketing instruments such as costly services, infrastructure elements such as checkout areas, and store atmospherics. Increasing service levels tends to be a costly undertaking, so retailers must determine whether those investments are likely to pay off; if the retailers mainly sell search goods, such as branded FMCGs, they might instead prioritize offering favorable prices, speedy service, and simpler layouts rather than higher service levels or more comfortable atmospheres. However, for experience goods, psychological utility provided by a high service level and appealing atmosphere is more important.

Changing positioning requires changing priorities. Many retailers that offer products for 
immediate consumption have adjusted their assortments to offer more health-oriented, fresh products, reflecting societal trends (Benoit et al., 2016). Our research informs these retailers that when they change their positioning, they also need to change their priorities related to the overall offering. For traditional assortments to support immediate consumption-such as those featuring prepackaged, branded products — the price level and speedy service are most important. If the assortment shifts toward healthier, often freshly prepared assortments, other criteria become more important - such as the atmosphere, service level, and assortment variety.

Importance of time and money. In on-the-go shopping situations, buying a search good increases the importance of economic utility. For retailers, especially those that operate a variety of formats, it means that consumers likely have different tolerances for waiting times and price levels - depending on the products they buy and not just on personal factors like (situational) time pressures or (more general) time consciousness and price sensitivity. For experience goods, consumers are more accepting of transaction costs related to waiting times or higher prices in their format selections.

Competitive landscape. For search goods, consumers consider a wider range of competitors, such that even the most preferred retailer competes with 1.65 other formats on average. For experience goods, the preferred retailer needs to compete with only 1.14 other formats. This link is even more pronounced for more frequent on-the-go shoppers. For retailers, shoppers with the highest overall frequency of on-the-go purchases may be their most disloyal customers. Instruments like loyalty cards could work to counteract these effects and might influence how consumers ultimately select a certain type of format.

\section{Limitations and further research}

Several limitations of our study suggest avenues for further research. We operationalize 
on-the-go shopping situations with different product types (bottled water / soft drinks and freshly prepared hot drinks). We also replicate the results for two additional search and experience goods (pre-packed snacks and freshly prepared snacks). However, our empirical focus is limited to two types of search products and two types of experience products. Thus, future research could investigate consumers' format selections of other food, non-food items, and beverage product categories - thereby comparing search products (low risk) and experience products (high risk) within each product category. The shopping situation is highly relevant for food items, prompting our focus on store-based grocery formats. Further research could include other product categories and formats such as online or hybrid formats like click and collect. Our online experiment refers to format selections over the previous four weeks, such that we do not capture the availability of formats at the moment that the need arises, which is a gap that should be addressed by further research. The main dependent variable compares the tolerable range of formats in two shopping situations, which suggests interesting insights into the different importance of format attributes; continued research might use conjoint analysis to reveal customer segments on the basis of these format selections. Finally, our empirical setting includes only developed retail environments with high store density and advanced retail infrastructure. Replication studies could look into developing environments. 


\section{References}

Alfnes, F., Rickertsen, K., \& Ueland, Ø. (2008). Consumer attitudes toward low stake risk in food markets. Applied Economics, 40, 3039-3049.

Arnold, S. J., Handelman, J., \& Tigert, D. J. (1996). Organizational legitimacy and retail store patronage. Journal of Business Research, 35, 229-239.

Baker, J., Parasuraman, A., Grewal, D., \& Voss, G. B. (2002). The Influence of multiple store environment cues on perceived merchandise value and patronage intentions. Journal of Marketing, 66, 120-141.

Balasubramanian, S., Raghunathan, R., \& Mahajan, V. (2005). Consumers in a multichannel environment: product utility, process utility and channel choice. Journal of Interactive Marketing, 19, 12-30.

Belk, R. W. (1974). An exploratory assessment of situational effects in buyer behavior. Journal of Marketing Research, 11, 156-163.

Bell, D. R., Ho, T.-H., \& Tang, C. S. (1998). Determining where to shop: fixed and variable costs of shopping. Journal of Marketing Research, 35, 352-369.

Benoit, S., Schaefers, T., \& Heider, R. (2016). Utilitarian, hedonic and hybrid determinants of on-the-go consumption. Journal of Retailing and Consumer Services, 31, 32-42.

Bhatnagara, A., \& Ratchford, B. T. (2004). A model of retail format competition for non-durable goods. International Journal of Research in Marketing, 21, 39-59.

Bloemer, J., \& de Ruyter, K. (1998). On the relationship between store image, store satisfaction and store loyalty. European Journal of Marketing, 32, 499-513.

Blut, M., Teller, C., \& Floh, A. (2018). Testing retail marketing-mix effects on patronage: A meta-analysis. Journal of Retailing, 94, 113-135. 
Chaudhuri, A. (1998). Product class effects on perceived risk: the role of emotion. International Journal of Research in Marketing, 15, 157-168.

Choudhury, V., Dumm, R., \& Karahanna-Evaristo, E. (1999). Consumer channel choices: the role of knowledge and choice uncertainty. In: Association for Information Systems AIS Electronic Library. Electronically published at: http://aisel.aisnet.org/amcis1999/178, accessed $13^{\text {th }}$ of March 2018.

Conchar, M. P., Zinkhan, G. M., \& Peters, C., Olavarrieta, S. (2004). An integrated framework for the conceptualization of consumers' perceived-risk processing. Journal of the Academy of Marketing Science, 32, 418-436.

Dellaert, B. G. C., Arentze, T. A., \& Timmermans, H. J. P. (2008). Shopping context and consumers' mental representation of complex shopping trip decision problems. Journal of Retailing, 84, 219-232.

Derbaix, C. (1983). Perceived risk and risk relievers. An empirical investigation. Journal of Economic Psychology, 3, 19-38.

Dholakia, U. M. (2001). A motivational process model of product involvement and consumer risk perception. European Journal of Marketing, 35, 1340-1362.

Ekelund, R. B., Mixon, F. G., \& Ressler, R. W. (1995). Advertising and information: an empirical study of search, experience and credence goods. Journal of Economic Studies, 22(2), 33-43.

Emmelhainz, M. A., Stock, J. R., \& Emmelhainz, L. W. (1991). Consumer Responses to Retail Stock-outs. Journal of Retailing, 67(2), 138-147.

Erdem, T., \& Swait, J. (1998). Brand equity as a signaling phenomenon. Journal of Consumer Psychology, 7, 131-157. 
Food Marketing Institute. (2015). U. S. Grocery shopping trends 2014 overview. Unpublished presentation, 1-22.

Fox, E. J., Montgomery, A. L., \& Lodish, L. M. (2004). Consumer shopping and spending across retail formats. The Journal of Business, 77, 25-60.

Goldsmith, R. E. Freiden, J.B., \& Eastman, J.K. (1995). The generality/specificity issue in consumer innovativeness research. Technovation, 15(10), 601-612

Gourville, J.T., \& Soman, D. (2005). Overchoice and assortment type: when and why variety backfires. Marketing Science, 24, 382-395.

Grewal, D., Baker, J., Levy, M., \& Voss, G. B. (2003). The effects of wait expectations and store atmosphere evaluations on patronage intentions in service-intensive retail stores. Journal of Retailing, 79, 259-268.

Heiman, A., \& Muller, E. (1996). Using Demonstration to Increase New Product Acceptance: Controlling Demonstration Time. Journal of Marketing Research, 33, 422-430.

Huang, P., Lurie, N. H. \& Mitra, S. (2009). Searching for Experience on the Web: An Empirical Examination of Consumer Behavior for Search and Experience Goods. Journal of Marketing, 73, 55-69.

Hunneman, A., Verhoef, P. C., \& Sloot, L. M. (2017). The moderating role of shopping trip type in store satisfaction formation. Journal of Business Research, 78, 133-142.

IGD. (2018). Coffee-to-go in convenience stores. Electronically published at: https://retailanalysis.igd.com/presentations/presentation-viewer/t/coffee-to-go-inconvenience-stores/i/7518, accessed $2^{\text {nd }}$ of March 2018.

Inman, J. J., Shankar, V., \& Ferraro, R. (2004). The roles of channel-category associations and geodemographics in channel patronage. Journal of Marketing, 68, 51-71. 
Ipsos. (2018). 10 Trends which are (re)shaping the Food \& Beverage Market, Food for Thought. Electronically published at: https://www.ipsos.com/sites/default/files/ct/news/documents/201807/10_trends_which_are_reshaping_the_fb_market.pdf, accessed $2^{\text {nd }}$ of November 2018 .

Jacoby, J., \& Kaplan, L. B. (1972). The components of perceived risk. In: M. Venkatesan (Ed.), Proceedings of the third annual conference of the association for consumer research (pp. 382-393). Chicago: Association for Consumer Research.

Kamran-Disfani, O., Mantrala, M. M., Izquierdo-Ysta, A., \& Martínez-Ruiz, M. P. (2017). The impact of retail store format on the satisfaction-loyalty link: An empirical investigation. Journal of Business Research, 77, 14-22.

Kushwaha, T., \& Shankar, V. (2013). Are multichannel customers really more valuable? The moderating role of product category characteristics. Journal of Marketing, 77, 67-85.

Maity, M., \& Dass, M. (2014). Consumer decision-making across modern and traditional channels: E-commerce, m-commerce, in-store. Decision Support Systems, 61, 34-46.

Mazursky, D., \& Jacoby, J. (1986). Exploring the development of store images. Journal of Retailing, 62, 145-165.

McGoldrick, P. (2002). Retail marketing. London: McGraw Hill.

Messinger, P. R., \& Narasimhan, C. (1997). A model of retail formats based on consumers' economizing on shopping time. Marketing Science, 16, 1-23.

Miller, K. E., \& Ginter, J. L. (1979). An investigation of situational variation in brand choice behavior and attitude. Journal of Marketing Research, 16, 111-123.

Mitchell, V-W. (1998). A role for consumer risk perceptions in grocery retailing. British Food Journal, 100, 171-183. 
National Association of Convenience Stores. (2017). NACS Fact Sheets. Electronically published at: https://www.convenience.org/Research/FactSheets, accessed $13^{\text {th }}$ of November 2018.

Nelson, P. (1970). Information and consumer behavior. Journal of Political Economy, 78(2), $311-329$.

Nielsen. (2015). The future of grocery, e-commerce, digital technology and changing shopping preferences around the world. Electronically published at: http://www.nielsen.com/uk/en/insights/reports/2015/the-future-of-grocery.html, accessed $12^{\text {th }}$ of July 2018.

Noble, S. M., Griffith, D. A. \& Weinberger, M. G. (2017). Consumer derived utilitarian value and channel utilization in a multi-channel context. Journal of Business Research, 58, 16431651.

Pan, Y., \& Zinkhan, G. M. (2006). Determinants of retail patronage: a meta-analytical perspective. Journal of Retailing, 82, 229-243.

PMA. (2017). How consumer trends in grocery shopping are changing retail. Electronically published at: https://www.pma.com/content/articles/2017/08/how-consumer-trends-in-groceryshopping-are-changing-retail, accessed $12^{\text {th }}$ of July 2018.

Popkowski Leszczyc, P. T. L., Sinha, A., \& Sahgal, A. (2004). The effect of multi-purpose shopping on pricing and location strategy for grocery stores. Journal of Retailing, 80, 85-99.

Popkowski Leszczyc, P. T. L., Sinha, A., \& Timmermanns, H. J. P. (2000). Consumer store choice dynamics: an analysis of the competitive market structure for grocery stores. Journal of Retailing, 76, 323-345. 
Popkowski Leszczyc, P. T. L., \& Timmermans, H. J. P. (2001). Experimental choice analysis of shopping strategies. Journal of Retailing, 77, 493-509.

Reutterer, T., \& Teller, C. (2009). Store format choice and shopping trip types. International Journal of Retail and Distribution Management, 37, 695-710.

Sheth, J. N., \& Venkatesan, M. (1968). Risk-reduction processes in repetitive consumer behavior. Journal of Marketing Research, 5, 307-310.

Sirohi, N., McLaughlin, E. W., \& Wittink, D. R. (1998). A model of consumer perceptions and store loyalty intentions for a supermarket retailer. Journal of Retailing, 74, 223-245.

Skoda, E. (2017). On-the-go: the trend that's here to stay. Electronically published at: https://packagingeurope.com/on-the-go-food-convenience-trend, accessed $2^{\text {nd }}$ of November 2018.

Srinivasan, S. S., \& Till, B. D. (2002). Evaluation of search, experience and credence attributes: role of brand name and product trial. Journal of Product \& Brand Management, 11, 417431.

Statista. (2017). Consumers' weekly grocery shopping trips in the United States from 2006 to 2016 (average weekly trips per household). Electronically published at: www.statista.com, accessed $14^{\text {th }}$ of August 2017.

Sweeney, J., Soutar, G. N., \& Johnson, L. W. (1999). The role of perceived risk in the qualityvalue relationship: a study in a retail environment. Journal of Retailing, 75, 77-105.

Thelen, E. M., \& Woodside, A. G. (1997). What evokes the brand or store? Consumer research on accessibility theory applied to modeling primary choice. International Journal of Research in Marketing, 14, 125-145. 
Teller, C., Kotzab, H., \& Grant, D. B. (2011). The relevance of shopper logistics for consumers of store-based retail formats, Journal of Retailing and Consumer Services, 19(1), 59-66.

Valentini, S., Montaguti, E., \& Neslin, S. A. (2011). Decision process evolution in customer channel choice. Journal of Marketing, 75, 72-86.

Van Kenhove, P., de Wulf, K. de, \& van Waterschoot, W. (1999). The impact of task definition on store-attribute saliences and store choice. Journal of Retailing, 75, 125-137.

Wallenius, J., Fishburn, P. C., Zionts, S., Dyer, J. S., Steuer, R. E., \& Deb, K. (2008). Multiple criteria decision making, multi attribute utility theory: recent accomplishments and what lies ahead. Management Science, 54, 1336-1349.

Watson IV, G. F., Worm, S., Palmatier, R. W., \& Ganesan, S. (2015). The evolution of marketing channels: trends and research directions. Journal of Retailing, 91, 546-568.

Weathers, D., Sharma, S., \& Wood, S. L. (2007). Effects of online communication practices on consumer perceptions of performance uncertainty for search and experience goods. Journal of Retailing, 83, 393-401.

Woodside, A. G., \& Trappey, R. III. (1992). Finding out why customer shop your store and buy your brand: Automatic cognitive processing models of primary choice. Journal of Advertising Research, 32, 59-87.

Zeithaml, V. A. (1988). Consumer perceptions of price, quality, and value: a means-end model and synthesis of evidence. Journal of Marketing, 52(3), 2-22. 
Table 1: Literature overview

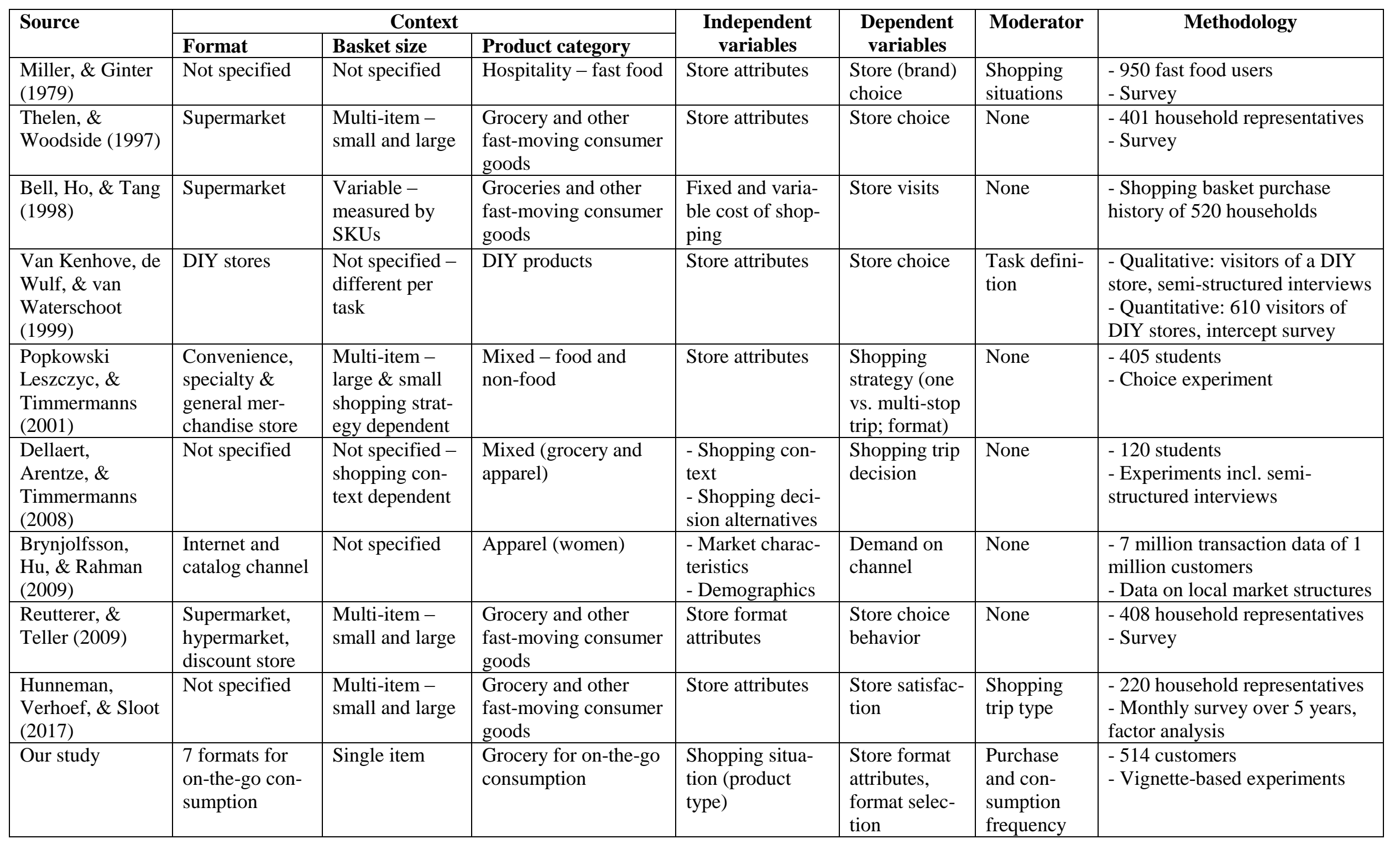


Table 2: Results, H1

\begin{tabular}{lllcc}
\hline & & & $\begin{array}{c}p \text {-Value } \\
\text { (one- } \\
\text { tailed) }\end{array}$ & $t$-Value \\
\hline Importance of functional format utility (H1a) & Search good & 35.985 & 0.038 & -2.847 \\
& Experience good & 38.831 & & \multirow{2}{*}{8.942} \\
Importance of economic format utility (H1b) & Search good & 52.668 & 0.000 & \\
& Experience good & 43.726 & & -6.096 \\
Importance of psychological format utility (H1c) & Search good & 11.348 & 0.000 \\
& Experience good & 17.443 & & \\
\hline
\end{tabular}




\section{APPENDIX: EXPERIMENTAL SETTING AND SURVEY ITEMS}

\section{Introduction and framing:}

This study investigates how and where you buy and consume food or drinks on the go (e.g., drinks, bars, filled rolls, or an entire meal). When on-the-go consumption is mentioned in the following questionnaire, it is referring to situations in which you are on your way home or to work and buy something to eat/drink promptly while you are still on your way. It can also refer to when you stop while you are on your way somewhere during leisure time to grab a snack/drink that you consume while on your way.

This means that we do not want to investigate situations of "normal" restaurant visits, in which you deliberately travel to a restaurant for this purpose. We also do not want investigate the consumption of meals in staff canteens or cafeterias provided by employers or educational institutions. Also, we do not include shopping situations in which you do your weekly grocery shopping or use home delivery / take-away from some restaurant.
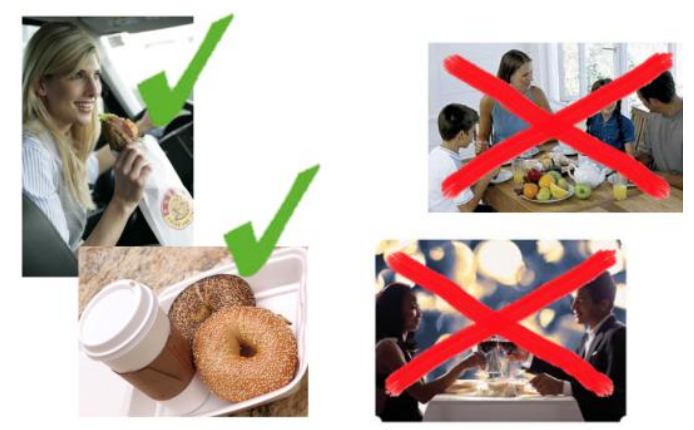

We are interested in your personal choice and your experience. There is no right or wrong answer, so please answer as honestly as possible.

\section{Experimental manipulation of search good versus experience good:}

\begin{tabular}{|l|l|}
\hline $\begin{array}{l}\text { You are on the go (to work, home from work, or } \\
\text { during leisure time) and want to buy a bottle of } \\
\text { water or a soft drink for immediate consump- } \\
\text { tion. }\end{array}$ & $\begin{array}{l}\text { You are on the go (to work, home from work, or } \\
\text { during leisure time) and want to buy a hot drink, } \\
\text { like coffee or tea, for immediate consumption. }\end{array}$ \\
\hline
\end{tabular}

\section{Survey items:}

\begin{tabular}{|l|l|}
\hline $\begin{array}{l}\text { Manipulation check risk: Please imagine the above situation, in which you } \\
\text { consume (repeat product from introduction), and rate the following state- } \\
\text { ments (7-point scale, very low - very high, } \alpha=.772) \text { : }\end{array}$ & Mean (SD) \\
\hline $\begin{array}{l}\text { What are the chances that there will be something wrong with products bought } \\
\text { for on-the-go consumption? }\end{array}$ & $2.56(1.46)$ \\
\hline
\end{tabular}




\begin{tabular}{|c|c|c|c|c|c|c|c|}
\hline \multirow{2}{*}{\multicolumn{6}{|c|}{$\begin{array}{l}\text { What are the chances that you stand to lose money if you consume a product to } \\
\text { go? } \\
\text { What are the chances that you are taking a risk with the bought product? }\end{array}$}} & \multicolumn{2}{|c|}{$3.49(1.78)$} \\
\hline & & & & & & \multicolumn{2}{|c|}{$2.49(1.48)$} \\
\hline \multicolumn{8}{|c|}{$\begin{array}{l}\text { Attribute importance: Please imagine the above situation, in which you consume } \\
\text { uct from introduction). Which of the following aspects is important to you? Please allocate } 100 \text { to the } \\
\text { following six aspects: }\end{array}$} \\
\hline \multirow[t]{2}{*}{ Functional utility } & \multicolumn{5}{|c|}{ _\% Quality of the assortment } & \multicolumn{2}{|c|}{$25.97(16.56)$} \\
\hline & \multicolumn{5}{|c|}{ — $\%$ Variety of the assortment } & \multicolumn{2}{|c|}{$14.97(11.58)$} \\
\hline \multirow[t]{2}{*}{ Economic utility } & \multicolumn{5}{|c|}{ — Price level } & \multicolumn{2}{|c|}{$23.70(16.46)$} \\
\hline & \multicolumn{5}{|c|}{ _\% Quick shopping } & \multicolumn{2}{|c|}{$20.59(16.14)$} \\
\hline \multirow[t]{2}{*}{ Psychological utility } & \multicolumn{5}{|c|}{ _\% Service } & \multicolumn{2}{|c|}{$8.68(7.46)$} \\
\hline & \multicolumn{5}{|c|}{ _\% Atmosphere } & \multicolumn{2}{|c|}{$6.08(6.29)$} \\
\hline \multicolumn{8}{|c|}{$\begin{array}{l}\text { Format selection: Please imagine the above situation on the go and try to remember the last four } \\
\text { weeks. Please indicate all the providers that you have visited to buy __ (repeat product from intro- } \\
\text { duction): }\end{array}$} \\
\hline \multicolumn{6}{|c|}{ _ Small supermarket (e.g., REWE To Go) (SM) } & \multicolumn{2}{|c|}{$.48(.50)$} \\
\hline \multicolumn{6}{|c|}{ _ Discounter (e.g., Aldi, Lidl) (DI) } & \multicolumn{2}{|c|}{$.27(.45)$} \\
\hline \multicolumn{6}{|c|}{ - Bakery (BA) } & \multicolumn{2}{|c|}{$.49(.50)$} \\
\hline \multicolumn{6}{|c|}{ _ Forecourt store at petrol station (FS) } & \multicolumn{2}{|c|}{$.42(.49)$} \\
\hline \multicolumn{6}{|c|}{ _ Corner shop $(\mathrm{CO})$} & \multicolumn{2}{|c|}{$.23(.42)$} \\
\hline \multicolumn{6}{|c|}{ _ Fast food restaurant (e.g., McDonald's, Subway) (FF) } & \multicolumn{2}{|c|}{$.36(.48)$} \\
\hline — Coffee shop (e.g. St & ucks, Se & fredo $)(\mathrm{C}$ & & & & $.23(.42$ & \\
\hline — None of these provi & & & & & & $.02(.14$ & \\
\hline $\begin{array}{l}\text { Expected utility of for } \\
\text { product from introducti } \\
\text { evaluate the experience }\end{array}$ & $\begin{array}{l}\text { Try to } \\
\text { - Pleaint sc } \\
\end{array}$ & $\begin{array}{l}\text { nagine th } \\
\text { nember } \\
\text {, very ne }\end{array}$ & $\begin{array}{l}\text { above sit } \\
\text { the expe } \\
\text { tive }- \text { ve }\end{array}$ & $\begin{array}{l}\text { ion, in } y \\
\text { nces witl } \\
\text { positive, }\end{array}$ & $\begin{array}{l}\text { ch you co } \\
\text { he below } \\
\text { ean (stan }\end{array}$ & $\begin{array}{l}\text { tail forme } \\
\text { rd deviat } \\
\text { rd }\end{array}$ & $\begin{array}{l}\text { (repeat } \\
\text { and } \\
\text { a)): }\end{array}$ \\
\hline & SM & DI & BA & FS & $\mathrm{CO}$ & FF & $\mathrm{CS}$ \\
\hline $\begin{array}{l}\text { Quality of the assort- } \\
\text { ment }\end{array}$ & $\begin{array}{l}5.67 \\
(1.11)\end{array}$ & $\begin{array}{l}4.95 \\
(1.44)\end{array}$ & $\begin{array}{l}5.91 \\
(1.06)\end{array}$ & $\begin{array}{l}4.72 \\
(1.42)\end{array}$ & $\begin{array}{l}4.31 \\
(1.45)\end{array}$ & $\begin{array}{l}4.31 \\
(1.61)\end{array}$ & $\begin{array}{l}5.24 \\
(1.27)\end{array}$ \\
\hline $\begin{array}{l}\text { Variety of the assort- } \\
\text { ment }\end{array}$ & $\begin{array}{l}5.80 \\
(1.19)\end{array}$ & $\begin{array}{l}4.96 \\
(1.44)\end{array}$ & $\begin{array}{l}5.23 \\
(1.34)\end{array}$ & $\begin{array}{l}4.53 \\
(1.39)\end{array}$ & $\begin{array}{l}4.05 \\
(1.40)\end{array}$ & $\begin{array}{l}4.50 \\
(1.52)\end{array}$ & $\begin{array}{l}4.81 \\
(1.37)\end{array}$ \\
\hline Price level & $\begin{array}{ll}5.23 \\
(1.31)\end{array}$ & $\begin{array}{l}5.77 \\
(1.19)\end{array}$ & $\begin{array}{l}4.18 \\
(1.50)\end{array}$ & $\begin{array}{l}3.43 \\
(1.64)\end{array}$ & $\begin{array}{l}3.63 \\
(1.39)\end{array}$ & $\begin{array}{l}4.05 \\
(1.56)\end{array}$ & $\begin{array}{l}3.36 \\
(1.54)\end{array}$ \\
\hline Speedy shopping & $\begin{array}{l}4.91 \\
(1.36)\end{array}$ & $\begin{array}{l}4.95 \\
(1.36)\end{array}$ & $\begin{array}{l}5.27 \\
(1.19)\end{array}$ & $\begin{array}{l}5.01 \\
(1.31)\end{array}$ & $\begin{array}{l}4.86 \\
(1.35)\end{array}$ & $\begin{array}{l}4.74 \\
(1.43)\end{array}$ & $\begin{array}{l}4.44 \\
(1.33)\end{array}$ \\
\hline Service & $\begin{array}{l}4.77 \\
(1.32) \\
\end{array}$ & $\begin{array}{l}4.07 \\
(1.47) \\
\end{array}$ & $\begin{array}{l}5.60 \\
(1.06) \\
\end{array}$ & $\begin{array}{l}4.37 \\
(1.35) \\
\end{array}$ & $\begin{array}{l}4.33 \\
(1.31) \\
\end{array}$ & $\begin{array}{l}4.36 \\
(1.41) \\
\end{array}$ & $\begin{array}{l}4.88 \\
(1.26) \\
\end{array}$ \\
\hline Atmosphere & $\begin{array}{l}4.68 \\
(1.34)\end{array}$ & $\begin{array}{l}3.82 \\
(1.51)\end{array}$ & $\begin{array}{l}5.45 \\
(1.13)\end{array}$ & $\begin{array}{l}3.85 \\
(1.47)\end{array}$ & $\begin{array}{l}3.74 \\
(1.39)\end{array}$ & $\begin{array}{l}4.04 \\
(1.46)\end{array}$ & $\begin{array}{l}4.91 \\
(1.33)\end{array}$ \\
\hline
\end{tabular}




\begin{tabular}{|l|l|}
\hline $\begin{array}{l}\text { When I'm out and about, I regularly buy something to eat or drink along the } \\
\text { way. }\end{array}$ & $3.09(1.36)$ \\
\hline I often spontaneously decide to buy some food or drinks to go. & $3.60(1.29)$ \\
\hline $\begin{array}{l}\text { In the near future, I will continue to regularly buy something to eat or drink } \\
\text { along the way. }\end{array}$ & $3.42(1.25)$ \\
\hline
\end{tabular}




\begin{tabular}{|c|c|c|c|c|c|}
\hline \multirow{2}{*}{\multicolumn{2}{|c|}{$\begin{array}{c}\text { Characteristics of the selection } \\
\text { process }\end{array}$}} & \multirow{3}{*}{\begin{tabular}{l}
\multicolumn{1}{c}{ Typical example } \\
Often national-branded, \\
manufactured products \\
such as a Coke or a Mars \\
bar
\end{tabular}} & \multicolumn{3}{|c|}{ Implications for quality, risk perception, and mitigation } \\
\hline & & & \multirow{2}{*}{\begin{tabular}{l}
\multicolumn{1}{c}{ Risk } \\
The perceived risk \\
of buying the \\
product is lower
\end{tabular}} & \multirow{2}{*}{\begin{tabular}{|l|}
\multicolumn{1}{|c}{ Quality } \\
Quality is secured \\
by the mass \\
production of the \\
manufacturer
\end{tabular}} & \multirow{2}{*}{$\begin{array}{l}\begin{array}{c}\text { Risk mitigation } \\
\text { strategy }\end{array} \\
\text { Rely more on } \\
\text { product brands }\end{array}$} \\
\hline $\begin{array}{l}\text { Search } \\
\text { goods }\end{array}$ & $\begin{array}{l}\ldots \text { can be evaluated } \\
\text { without interacting } \\
\text { with the product } \\
\text { through second- } \\
\text { hand information }\end{array}$ & & & & \\
\hline $\begin{array}{l}\text { Experience } \\
\text { goods }\end{array}$ & $\begin{array}{l}\ldots \text { require } \\
\text { interaction with the } \\
\text { product, potentially } \\
\text { through someone's } \\
\text { senses }\end{array}$ & $\begin{array}{l}\text { Often non-branded, } \\
\text { freshly prepared products } \\
\text { such as a freshly prepared } \\
\text { coffee or salad }\end{array}$ & $\begin{array}{l}\text { The perceived risk } \\
\text { of buying the } \\
\text { product is higher }\end{array}$ & $\begin{array}{l}\text { Quality is } \\
\text { influenced by the } \\
\text { preparation process } \\
\text { of the retailer }\end{array}$ & $\begin{array}{l}\text { Rely on retailer } \\
\text { image }\end{array}$ \\
\hline
\end{tabular}




\begin{tabular}{|c|c|c|c|}
\hline $\begin{array}{l}\text { Shopping } \\
\text { situation }\end{array}$ & $\begin{array}{l}\text { Format attribute } \\
\text { importance }\end{array}$ & $\begin{array}{c}\text { Expected } \\
\text { attribute utility }\end{array}$ & Format selection \\
\hline $\begin{array}{l}\text { - Search good } \\
\text { (bottled water or } \\
\text { soft drink) } \\
\text { - Experience good } \\
\text { (hot drink, e.g., } \\
\text { freshly prepared } \\
\text { coffee) }\end{array}$ & \multicolumn{2}{|c|}{$\begin{array}{l}\text { - Importance of utility dimensions: } \\
\text { - Quality \& variety (functional format utility) } \\
\text { - Price level \& speed (economic format utility) } \\
\text { - Service \& atmosphere (psychological format } \\
\text { utility) } \\
\text { - Expected (overall) utility of each format }\end{array}$} & $\begin{array}{l}\text { Format selection, e.g.: } \\
\text { supermarket, discount store, } \\
\text { convenience store, specialty } \\
\text { store, corner shop, fast food } \\
\text { restaurant, coffee shop }\end{array}$ \\
\hline $\begin{array}{l}\text { Variable: } \\
\text { Experimental } \\
\text { manipulation }\end{array}$ & \multicolumn{2}{|c|}{$\begin{array}{l}\text { Data: Survey items, variable calculated: } \\
\text { Weighted expected utility of format = importance } \\
\text { of each attribute } x \text { expected utility of each } \\
\text { attribute ( see Figure 2) }\end{array}$} & $\begin{array}{l}\text { Data: Survey items, variable } \\
\text { calculated: } \\
\text { Tolerable range of formats }= \\
\text { sum of expected utility of } \\
\text { chosen formats (see Figure } 3 \text { ) }\end{array}$ \\
\hline
\end{tabular}


Figure 3 Format attribute importance

Participants allocate share of $100 \%$ importance to six format attributes

\begin{tabular}{|l|c|c|c|}
\hline \multirow{2}{*}{$\begin{array}{l}\text { Format } \\
\text { attributes }\end{array}$} & \multicolumn{3}{|c|}{ Respondents } \\
\cline { 2 - 4 } & $\mathrm{A}$ & $\mathrm{B}$ & $\mathrm{C}$ \\
\hline Quality & $50 \%$ & $20 \%$ & $\ldots$ \\
\hline Variety & $10 \%$ & $20 \%$ & $\ldots$ \\
\hline Price level & $0 \%$ & $30 \%$ & $\ldots$ \\
\hline Speed & $20 \%$ & $10 \%$ & $\ldots$ \\
\hline Service & $10 \%$ & $10 \%$ & $\ldots$ \\
\hline Atmosphere & $10 \%$ & $10 \%$ & $\ldots$ \\
\hline
\end{tabular}

Expected utility of format

Participants evaluate the expected utility (cost/benefit ratio) of a format from negative

(1) to positive (7)

\begin{tabular}{|c|c|c|c|}
\hline $\begin{array}{c}\text { Respondent A: } \\
\text { exp. format } \\
\text { utility }\end{array}$ & 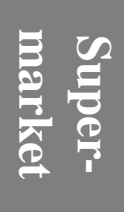 & $\begin{array}{l}\text { ㅂ.̆․ } \\
\text { है } \\
\text { ह }\end{array}$ & $\vdots$ \\
\hline Quality & 5 & 3 & $\ldots$ \\
\hline Variety & 6 & 3 & ... \\
\hline Price level & 2 & 7 & $\ldots$ \\
\hline Speed & 3 & 6 & $\ldots$ \\
\hline Service & 3 & 2 & $\ldots$ \\
\hline Atmosphere & 4 & 1 & $\ldots$ \\
\hline
\end{tabular}

Calculation of importance of all six retail attributes (e.g., $50 \%$ ) x expected utility (e.g., 5)

\begin{tabular}{|c|c|c|c|c|c|}
\hline \multirow{3}{*}{$\begin{array}{l}\text { Respondent A } \\
\text { Quality }\end{array}$} & \multirow{2}{*}{\multicolumn{2}{|c|}{$\begin{array}{l}\text { Supermarket } \\
\text { Importance * } \\
\text { expected utility }\end{array}$}} & \multicolumn{2}{|c|}{ Discounter } & \multirow{3}{*}{$\cdots$} \\
\hline & & & \multicolumn{2}{|c|}{$\begin{array}{l}\text { Importance * } \\
\text { expected utility }\end{array}$} & \\
\hline & $50 \times 5$ & 250 & $50 \times 3$ & 150 & \\
\hline Variety & $10 \times 6$ & 60 & $10 \times 3$ & 30 & \\
\hline Price level & $0 \times 2$ & 0 & $0 \times 7$ & 0 & \\
\hline Speed & $20 \times 3$ & 60 & $20 \times 6$ & 120 & \\
\hline Service & $10 \times 3$ & 30 & $10 \times 2$ & 20 & \\
\hline Atmosphere & $10 \times 4$ & 40 & $10 \times 1$ & 10 & \\
\hline $\begin{array}{l}\text { Weighted } \\
\text { expected utility }\end{array}$ & & 440 & & 330 & $\ldots$ \\
\hline
\end{tabular}

Weighted expected utility of each format 
Figure 4
Weighted expected utility of each format

\begin{tabular}{|l|c|c|c|}
\hline & \multicolumn{3}{c}{ Respondents } \\
\hline Supermarket & 410 & 230 & $\ldots$ \\
\hline Discounter & 270 & 120 & $\ldots$ \\
\hline Bakery & 420 & 510 & $\ldots$ \\
\hline Forecourt store & 300 & 430 & $\ldots$ \\
\hline Corner shop & 100 & 300 & $\ldots$ \\
\hline Fast food & 280 & 320 & $\ldots$ \\
\hline Coffee shop & 450 & 230 & $\ldots$ \\
\hline
\end{tabular}

\section{Format selection}

\begin{tabular}{|l|c|c|c|}
\hline & \multicolumn{3}{c}{ Respondents } \\
\hline Supermarket & Y & B & C \\
\hline Discounter & NO & $\ldots$ \\
\hline Bakery & YES & YES & $\ldots$ \\
\hline Forecourt store & YES & YES & $\ldots$ \\
\hline Corner shop & NO & NO & $\ldots$ \\
\hline Fast food & NO & NO & $\ldots$ \\
\hline Coffee shop & YES & NO & \\
\hline
\end{tabular}

\section{Tolerable range of formats}

\section{Examples}

Respondent A selected formats:

- $1^{\text {st }}$ highest score: Bakery (420)

- $2^{\text {nd }}$ highest score: Coffee shop (450)

- $3^{\text {rd }}$ highest score: Supermarket (410)

- $4^{\text {th }}$ highest score: Forecourt store (300)

Tolerable range: $420-300=\mathbf{1 2 0}$

Respondent B selected formats:

- $1^{\text {st }}$ highest score: Bakery (510)

- $2^{\text {nd }}$ highest score: Coffee shop (430)

Tolerable range: $510-430=\mathbf{8 0}$ 


\section{Retail Format Selection in On-the-Go Shopping Situations}

\section{Highlights}

- Research focus: impact of an on-the-go situation on retail format selection.

- For goods that are easy to evaluate before consumption (search good; e.g., can of Coke), a format's price level and speed are more important.

- For goods that are hard to evaluate before consumption (experience good; e.g., salad), the quality, variety, atmosphere, and service are more important.

- More formats are relevant when shopping for search goods compared to experience goods.

- Frequent on-the-go shoppers consider even more formats when shopping for search goods compared to experience goods. 
Sabine Benoit joined Surrey Business School, Department of Marketing and Retail Management, UK as a Professor of Marketing in 2016. Since 2019 she also has an affiliation to the College of Business and Economics at Australian National University (ANU). Beyond this and since 2008 she is Director of the Competence Center for On-the-go Consumption funded by Lekkerland $\mathrm{GmbH} \& \mathrm{Co.KG}$ a European Wholesale company. Before she was Professor of Marketing at Roehampton Business School and EBS Business School, Wiesbaden, Germany. Before she was Assistant Professor at the WHU - Otto Beisheim School of Management in Vallendar, Germany. Her main research fields are Service and Retail Marketing. Her work has been published in leading international Journals such as the Journal of Service Research, Journal of Operations Management or Psychology \& Marketing. In 2017 she received a best paper award (2nd) from the Journal of Service Research and Journal of Services Marketing in 2018 she received the best paper award from the Journal of Service Management. She is in the Editorial Board of Journal of Service Research (JSR), Journal of Service Management (JoSM), Journal of Services Marketing (JSM) and Journal of Business Research (JBR).

Heiner Evanschitzky is Professor and Chair of Marketing at Aston University and Director of the Aston Centre for Retail Insights. Heiner received his PhD and Habilitation from the University of Muenster (Germany). His research investigates interesting and relevant problems with an attempt to develop impactful conclusions. The current focus primarily lies in Retail Marketing/Management where he investigates customer inspiration and store atmospherics, customer participation, relationship marketing, and profit chain models. His work has been published in journals such as Journal of Marketing, Journal of the Academy of Marketing Science, Journal of Retailing, Journal of Service Research, International Journal of Research in Marketing, and Journal of Product Innovation Management. Heiner currently serves as Associate Editor for the British Journal of Management.

Christoph Teller is Chair in Retailing and Marketing at the University of Surrey, Guildford, UK. Before he worked for ten years as an Assistant Professor at the Institute for Retailing and Marketing - the oldest retail-institute in Central Europe - part of the Vienna University of Economics and Business (Austria). During that time, he spent almost a year at the Department of Operations Management of the Copenhagen Business School as a visiting professor. Afterwards he taught/researched for three and a half years as a Senior Lecturer (Associate Professor) at the renowned Institute for Retail Studies at the University of Stirling (Scotland). Besides this, he also gained practical experience in the fields of retailing (operations, distribution and marketing), consulting (retail, NPO) and market(ing) research. His work is published in leading journals, such as the Industrial Marketing Management, International Journal of Physical Distribution and Logistics Management and Journal of Retailing. 